\title{
Developing a relational law of contracts: striking a balance between abstraction and contextualism
}

\author{
Zoe Gounari ${ }^{* \dagger}$ (iD \\ Durham Law School, Durham University, Durham, UK \\ *Author email: zoe.gounari@durham.ac.uk
}

(Accepted 20 May 2020)

\begin{abstract}
Relational contract theory holds that the interpretation of a contract must take full account of the context and surrounding circumstances of the parties' bargain so as to give effect to their respective intentions. This paper argues that if a relational treatment of contracts is to be institutionalised, in the sense of being utilised in a contract dispute to determine and give effect to the parties' intentions, then it must operate at an abstract level. That is to say, rather than using relevant context to determine what the actual parties intended in the circumstances at hand, the contextualist enquiry should ascertain the relevant context by reference to what the parties would have agreed to in the circumstances, had they properly reflected on what their self-interest requires. I discuss the merits of this proposition by reference to a number of appellate judgments, which already endorse contextualism as a response to contractual ambiguity, and I ultimately apply it to the Supreme Court's judgment in Rainy Sky SA v Kookmin Bank.
\end{abstract}

Keywords: relational contracts; contract theory; contract interpretation

\section{Introduction}

The 'relational contract' recently became the basis for controversy in English contract law, when Lord Leggatt, sitting at first instance, relied on this concept to justify implying a duty of good faith into an oral contract between two highly sophisticated parties. ${ }^{1}$ The contract concerned a joint venture formed between an investor and an hotelier for the purpose of buying and developing a number of luxury hotels in Greece. The learned judge identified the joint venture as a paradigmatic relational contract, because it was informal, yet required a high degree of cooperation between the parties and, as such, gave rise to mutual expectations of confidence and trust so as to achieve the venture's common objective. ${ }^{2}$ These expectations could only be given legal effect, he reasoned, if a duty could be implied into the contract requiring the parties to conduct the joint venture's affairs in good faith. To be sure, Lord Leggatt's conclusion as to good faith and its place in the performance of such contracts was controversial in its own right, not least because it contradicted established contract law orthodoxy, which tends to treat contract parties as adversaries and even has a place for opportunistic breaches of contract pursuant to strategies of 'efficient breach'. To my mind, however, the controversy does not lie in the nature of the implied duty, but in the starting premise of the learned judge's reasoning - the relational contract. For one, an attempt to rely on relational contract

${ }^{\dagger}$ I am grateful to the anonymous reviewer and those who have read and commented on earlier drafts of this paper, particularly Chris Riley, Matthew Nicholson and Shaun Pattinson, as well as the participants of the Private Law Consortium, which took place at Bar Ilan University, Tel Aviv, between 3-4 June 2019. All errors are mine.

${ }^{1}$ Al Nehayan v Kent [2018] EWHC 333 (Comm).

${ }^{2}$ Ibid, at [174], building on his argument in Yam Seng Pte Ltd v International Trade Corp [2013] EWHC 111 (Comm). 
jurisprudence for the purpose of implying terms into existing contracts had previously been dismissed in the Court of Appeal for lack of certainty. ${ }^{3}$ Yet, Al Nehayan was the latest in a string of High Court cases, ${ }^{4}$ indicating that the concept of a relational contract has transcended the realm of abstract theory and become the basis of applied judicial reasoning with some persuasive, if not outright precedential, force.

If this is correct, the key question is: how should the tenets of relational contract theory be implemented by the courts? The purpose of this paper is to set out an interpretative framework by which to operationalise relational contract law. I argue that relational contract theory provides the essential means by which to rationalise the application of contract law, in the sense of bringing it in line with its own declared objective of giving effect to the parties' reasonable expectations. However, in contrast to most relational contract theorists, I argue that the relational methodology should be implemented at an abstract level. That is to say, the relational methodology should be used to establish what a reasonable economic agent would have intended in the parties' circumstances (objective level), rather than what the actual parties intended in those circumstances (subjective level). In order to more accurately ascertain the intentions of such an agent, I argue that contract law should rely on the relational methodology to recalibrate its presumptions on the nature of the reasonable agent. To do this, contract law must take into account the circumstances surrounding the contract and shaping the dispositions of the agents at its core. This is a marked departure from relational theory proper, which, in contrast to current legal orthodoxy, advocates absolute contextualism in the interpretation of contracts. Nevertheless, I consider my argument to be distinctly relationalist because it stems from the fundamentally relational concept of viewing the contract as a collaborative undertaking first and foremost, rather than as a transaction between adversaries.

My argument and proposed interpretative framework are based on three presumptions, which I set out below. For the first two, I will provide only outline justifications as they appear in the law, while, in the next section, I will expand on and justify the third. The first of these presumptions is that the objective of contract law is to give effect to the reasonable expectations of the parties, ${ }^{5}$ given that ascertaining their intentions at the time of contracting is the paramount undertaking in English contract law. ${ }^{6}$ This is evidenced by the requirement that the parties must have intended the creation of legal relations before a contract can be said to have come into existence. ${ }^{7}$ Furthermore, the primary statute on the commercial sale of goods, the Sale of Goods Act 1979, for the most part defers to the intentions of the parties to determine whether certain statutory provisions will apply to the contractual relationship and, if so, how. ${ }^{8}$

The second presumption is that the law's understanding of rationality is that it lies in the pursuit of one's self-interest (within the bounds of the law). This is amply illustrated by Lord Ackner's famous statement in Walford $v$ Miles, in response to counsel arguing that contractual bargaining must be done in good faith when the defendants defected on an agreement to exclusively negotiate with the claimant for the sale of a company:

The concept of a duty to carry on negotiations in good faith is inherently repugnant to the adversarial $[s i c]$ position of the parties when involved in negotiations. Each party to the negotiations is entitled to pursue his (or her) own interest, so long as he avoids making misrepresentations. ${ }^{9}$

\footnotetext{
${ }^{3}$ Baird Textile Holdings Ltd v Marks \& Spencer plc [2001] EWCA Civ 274 (discussed in detail below).

${ }^{4}$ Globe Motors v TRW Lucas Varity Electric Steering Ltd [2016] EWCA Civ 396; DઐG Cars Ltd v Essex Police Authority [2015] EWHC 226 (Comm); Bristol Groundschool Ltd v Intelligent Data Capture Ltd [2014] EWHC 2145 (Comm); Yam Seng Pte Ltd $v$ International Trade Corp, above n 2.

${ }^{5}$ See the relevant discussion in J Steyn 'Contract law: fulfilling the reasonable expectations of honest men' (1997) Law Quarterly Review 433.

${ }^{6}$ See eg Couturier $v$ Hastie [1856] 5 HLC 673, in the context of goods having perished at the time of the contract.

${ }^{7}$ Esso Petroleum Ltd $v$ Commissioners of Customs and Excise [1975] UKHL 4; Jones v Padavatton [1968] EWCA Civ 4; Errington $v$ Wood [1951] EWCA Civ 2; and see London and Regional Developments Ltd v TBI plc [2002] EWCA Civ 355 at $[38]$.

${ }^{8}$ Ample examples are ss 17, 19 and 20 of the Sale of Goods Act 1979, to the effect that property and risk in goods is to pass when the parties intend it to pass.

${ }^{9}$ [1992] 2 AC 128 at $138 \mathrm{E}$.
} 
My third presumption is that all contracts, no matter their type, length or subject matter, are relational at their core. The impact of this presumption is twofold. First, it renders a relational interpretation of contract law immediately operable; contract law need not amend its fundamental tenets but merely recalibrate its application of them. Secondly, it entails that a relational interpretation of contracts is more apt to determine and give effect to the parties' reasonable expectations than the current legal orthodoxy, which treats the context informing the relationship between the parties as relevant only in cases of contractual ambiguity. ${ }^{10}$ I expand on and justify this point in the next section.

The rest of the paper is structured as follows. In the next section, I set out the basic tenets of relational contract theory and contrast its methodology to that of the current legal orthodoxy. In section 2 I set out the practical and theoretical limitations of the relationalist approach and argue that these limitations of absolute contextualism render the operationalisation of relational contract theory impractical beyond a purely procedural level. In the final section, I set out an interpretative framework which examines how rational agents would reason in the broader context in which the contractual relationship operates, if they had properly reflected on what their self-interest requires.

\section{Relational contracts - a brief background}

The relational theory of contract defines contract as 'exchange relations', ${ }^{11}$ namely 'relations among people who have exchanged, are exchanging, or expect to be exchanging in the future, ${ }^{12}$ and upon the relationship ${ }^{13}$ created by an exchange of promises between two or more individuals. It is this relationship, which distinguishes this exchange from those which are 'discrete', namely bargains made on a one-off basis and are deemed concluded, ${ }^{14}$ where performance of the parties' respective obligations is completed on the spot or at a specific future point. ${ }^{15}$ A contract, which creates a relationship beyond the elementary interaction necessary ${ }^{16}$ for the one-off exchange and performance of mutual promises, is a 'relational contract'. ${ }^{17}$ On this foundation, relational contract theory holds that when the law undertakes to construe and enforce a relational contract, it must take into account the (social, cultural and financial) context of the parties' bargain as well as its surrounding circumstances, so as to properly comprehend the relationship and give effect to the parties' intentions. On this view, therefore, the formal contract between the parties is only one of the factors that determine the parties' respective rights and duties.

The relational theory of contracts developed as a response to the perceived failings of classical contract law, ${ }^{18}$ which holds the parties' express bargain as paramount. Thus, for the purpose of construing

\footnotetext{
${ }^{10}$ Arnold $v$ Britton [2015] UKSC 36; and see the relevant discussion in sections 2 and 3 below.

${ }^{11}$ I Macneil 'Relational contract theory: challenges and queries' (2000) 94 Northwestern University Law Review 877 at 877.

${ }^{12}$ Ibid.

${ }^{13}$ See M Eisenberg 'Relational contracts' in J Beatson and D Friedman (eds) Good Faith and Fault in Contract Law (Oxford: Clarendon Press, 1995) p 291; but note: Eisenberg does not define 'relationship' beyond the term's everyday meaning and therefore he does not attempt to distinguish when a 'relationship' borne out of a series of discrete exchanges, as per the facts of Baird, above n 3, gives rise to legally binding rights and duties, if at all.

${ }^{14}$ See eg the definition of the paradigmatic discrete transaction in V Goldberg 'Toward an expanded economic theory of contract' (1976) 10(1) Journal of Economic Issues 45 at 49.

${ }^{15}$ Specificity, either of timing or other performance-related characteristics, being a major characteristic of 'complete' contracts: eg see the analogy in G Hadfield 'Problematic relations: franchising and the law of incomplete contracts' (1990) 42 Stanford Law Review 927; cf C Goetz and R Scott 'Principles of relational contracts' (1981) 67 Virginia Law Review 1089 at 1091.

${ }^{16} \mathrm{Eg}$ another defining characteristic of a relational contract is that of extended interdependence: L Komhauser 'Book review: the resurrection of contract' (1990) 82 Columbia Law Review 184 at 188.

${ }^{17}$ To be sure, this is an unfairly simplistic account of relational contracts and is presented here in these terms for the sake of brevity. It should be noted that, if anything, the most debated and problematic issue in relational contract theory lies in the very definition of a relational contract: see R Speider 'The characteristics and challenges of relational contracts' (2000) 94 Northwestern University Law Review 823.

${ }^{18} \mathrm{Eg}$ I Macneil 'Contracts: adjustment of long-term relations under classical, neoclassical and relational contract law' (1978) 72 Northwestern University Law Review 854.
} 
and giving effect to the bargain, where the contractual language is clear and unambiguous, classical theory excludes the surrounding circumstances and the parties' subjective intentions or understanding at the time of contracting, ${ }^{19}$ unless these factors are made relevant by being expressly referred to in the agreement itself. Instead, the bargain's surrounding context is only relevant where the contractual language is ambiguous and creates competing, but plausible, ${ }^{20}$ interpretations. ${ }^{21}$ The purpose of this approach is to ensure that when called upon to construe and enforce the agreement, the law does not unduly interfere with the parties' fundamental freedom 'to contract as they may see fit ${ }^{22}$ by taking account of irrelevant factors. Subject to some well-defined limitations, this freedom applies with respect to all contracts apart from those whose subject matter is governed by a specific statutory regime (such as contracts for the conveyance of land, insurance, employment, consumer credit, etc).

There are two principal consequences of classical contract theory in practice. First, as regards the enforceability of the contract, unless there is a defect in the bargaining process (such as fraud, misrepresentation, mistake, duress or undue influence) which would undermine the validity of the parties' consent to the bargain, ${ }^{23}$ courts do not have a general power to alter a contract, for instance, in order to address a fundamental change in the circumstances of the original bargain. ${ }^{24}$ Neither can they refuse to enforce an otherwise valid contract (ie where there are no questions as to the capacity of the parties or the legality of the subject matter), even where its effect is unreasonable or unconscionable. ${ }^{25}$ In the words of Jessel MR:

if there is one thing which more than another public policy requires it is that men of full age and competent understanding shall have the utmost liberty of contracting, and that their contracts when entered into freely and voluntarily shall be held sacred and shall be enforced by Courts of justice. Therefore, you have this paramount public policy to consider - that you are not lightly to interfere with this freedom of contract. ${ }^{26}$

The second practical consequence of classical contract theory concerns the parties' performance of the contract. Thus, when performing their respective obligations, generally speaking, the parties cannot deviate from what the contract specifies. Any such deviation would technically amount to a breach of the contract and expose the 'non-performing' party to liability in damages. For example, in Arcos $v$ Ronaasen, ${ }^{27}$ the House of Lords upheld the buyer's strict right to reject goods for not complying with their description in the contract, despite their only negligible deviation from the contract specification. The case concerned an agreement for the sale and transport of Russian timber to an English buyer, who intended to use the goods for the construction of cement barrels with the seller's knowledge of this. The agreement stipulated the length, breadth and thickness of the staves to be delivered, and allowed for variation of the breadth and length of the staves, but not of their thickness, stipulated at a half inch. The staves the seller sought to deliver deviated from that specification by various degrees but in every case no more than a fraction above or below the specified half inch. Regardless, the buyer sought to reject the goods outright. The matter was referred to an umpire who determined that the

\footnotetext{
${ }^{19}$ Eg Arnold v Britton, above n 10, where the Supreme Court considered the interpretation of wording concerning a service charge in a 99 -year lease.

${ }^{20}$ On this point, see Braganza $v$ BP Shipping Ltd [2015] UKSC 17.

${ }^{21}$ Rainy Sky SA v Kookmin Bank, discussed below.

${ }^{22}$ Suisse Atlantique Société D'Armement Maritime SA v Rotterdamsche Kolen Centrale [1967] 1 AC 361 at 399D per Lord Reid.

${ }^{23}$ See National Westminster Bank plc v Morgan [1985] AC 686 at 708.

${ }^{24}$ See British Movietonews Ltd $v$ London and District Cinemas Ltd [1952] AC 166.

${ }^{25} \mathrm{Ibid}$, in the context of exclusion or exemption clauses; Photo Production Ltd $v$ Securicor Transport Ltd [1980] AC 827 at 848. On the implication of terms into a contract: The Moorcock (1889) 14 PD 64 at 68 and Luxor (Eastbourne) Ltd v Cooper [1941] AC 108 at 137; cf Ingham v Emes [1955] 2 All ER 740, where the Court effectively invented a good faith obligation in order to deny a frivolous claimant a remedy.

${ }^{26}$ Printing and Numerical Registering Co. v Sampson (1875) LR 19 Eq 462 at 465.

${ }^{27}$ [1933] AC 470; cf Cehave NV v Bremer Handelsgesellschaft mbh (The Hansa Nord) [1976] QB 44.
} 
staves were still suitable for the construction of barrels and, when shipped, the timber had been merchantable under the agreed specification. When the issue reached the House of Lords, it was held that the buyer was entitled to demand goods answering the description in the contract. According to Lord Buckmaster,

If the article they have purchased is not in fact the article that has been delivered, they are entitled to reject it, even though it is the commercial equivalent of that which they have bought. ${ }^{28}$

In other words, with respect to the performance of contractual obligations, classical contract theory translates into a regime of strict liability.

By contrast, relational theory holds that classical contract law is too rigid in its interpretation of the contract and its insistence on upholding the bargain as recorded in the parties' express agreement (if present) fails to take into account their actual contractual behaviour, which tends to evolve beyond the confines of what is prescribed in the agreement itself. ${ }^{29}$ Classical contract law also fails to address the problem of 'incomplete presentiation', ${ }^{30}$ namely the fact that it is impossible for the parties to contract in the present about every eventuality that befalls their relationship in the future. This is because, as Beale puts it, classical contract law tends to treat 'the contract in an abstract way, taking little account of the context in which it is made. ${ }^{31}$

On the other hand, relational theory advocates absolute contextualism. In Hillman's words, 'the thrust of relationalism is its description of reality'. ${ }^{32}$ Thus, the relationalist approach has no use for an a priori framework by which the court is to impute a set of expectations onto the parties, based on what a reasonable person in the parties' position would have intended, as is the case with the current legal position. This is because if an examination of the context informing the parties' relationship so warrants, a relational interpretation of contract rules could well afford the injured party with an appropriate remedy where the bargain is incomplete on that front or, theoretically, even where no express bargain had been previously hammered out. ${ }^{33}$ In other words, the relationalist's argument is that interpreting contracts through a universally applicable lens, which is by definition what the current objective legal framework entails, is cumbersome and ignores the reality of the parties' relationship and actual intentions. Thus, in the event of a dispute, the parties can be reasonably expected to settle their differences through negotiation and compromise, rather than through formal means. ${ }^{34}$ But

\footnotetext{
${ }^{28}[1933]$ AC 470 at 474.

${ }^{29}$ See I Macneil 'Relational contract: what we do and do not know' (1985) Wisconsin Law Review 483. For an economic perspective, see Goldberg, above n 14; cf I Macneil 'Efficient breach of contract: circles in the sky' (1982) 68(5) Virginia Law Review 947.

${ }^{30}$ 'Presentiation' being defined as the parties' attempt 'to bring all the future relating to [the transaction] into the present, or ..., to presentiate. [The parties] can then deal with the future as if it were in the present'; I Macneil The New Social Contract: An Inquiry into Modern Contractual Relations (New Haven: Yale University Press, 1980) p 19. For a general discussion of the 'incomplete presentiation' problem see D Campbell and J Harris 'Flexibility in long-term contract relationships: the role of cooperation' (1993) Journal of Law \& Society 166 at 169.

${ }^{31} \mathrm{H}$ Beale 'Relational values in English contract law' in D Campbell et al (eds) Changing Concepts of Contract: Essays in Honour of Ian Macneil (Basingstoke: Palgrave Macmillan, 2013) p 116 at p 117.

${ }^{32} \mathrm{R}$ Hillman The Richness of Contract Law: An Analysis and Critique of Contemporary Theories of Contract Law (Dordrecht: Springer Netherlands, 1997) p 265.

${ }^{33}$ Which should also correspond to the relational characteristics of the contract at issue and therefore the needs of the parties: see Macneil (1982), above n 29.

${ }^{34}$ See eg S Macaulay 'Non-contractual relations in business: a preliminary study' (1963) 28(1) American Sociological Review 55 and H Beale and T Dugdale 'Contracts between businessmen: planning and the use of contractual remedies' (1975) 2 British Journal of Law \& Society 45. See also Crystal's survey of cases brought under Article 2 of the United States Uniform Commercial Code (which imposes inter alia a duty of good faith on parties to commercial contracts and includes 'past dealings' as a factor to be considered in the interpretation of such contracts - a distinctly relational approach) demonstrating that the majority of litigated cases over a period of two decades involved 'discrete' contracts: N Crystal 'An empirical view of relational contracts under article two of the Uniform Commercial Code' (1988) Annual Survey of American Law 293 at 299.
} 
should attempts at an amicable solution fail, the court can and should settle the dispute by examining the specific circumstances underlying the parties' agreement and the overall context informing their relationship. Rather than attempting to regulate the conduct of contractual parties (for instance, in an attempt to protect the vulnerable following an unforeseen, or inadequately planned for, relationship-altering event) through an a priori framework, the interests of commercial actors would be better served by giving effect to their bargain as informed by the circumstances specific to each relationship. This approach, therefore, affords the parties and the courts the flexibility necessary to address one important empirical observation: the more 'relational' the exchange, the more unlikely it is that the parties will have planned and allocated risks effectively. ${ }^{35}$

In the same vein, relational theory can arguably provide an effective solution to the problem of opportunistic behaviour, which for instance inevitably faces rational commercial parties involved in a long-term collaborative relationship. Insisting on the importance of subjectivity, relational contract theory holds that ex hypothesi each case must be examined on its own facts and the application of contract law, as well as the award of any remedies, must reflect the context of the particular relationship. ${ }^{36}$ Thus, should a contractual relationship break down as a result of opportunism, the relational interpretation of the agreement would take into account both the specific circumstances underlying the agreement and the overall context of the relationship. On this basis, the court would be better placed to identify actions as opportunistic, which from a classical contract point of view might have been treated as both reasonable and foreseeable (and thus preventable through relevant provision in the agreement). ${ }^{37}$ Therefore, a relational application of contract law would be better placed overall to distinguish, according to context, between opportunism and fair dealing, and thus protect the vulnerable party and deter truly opportunistic behaviour in a contract, because its subjective approach would more accurately reflect the reality of the relationship. ${ }^{38}$

Against this background, I contend that contract law should operate on the presumption that, as Eisenberg argues, all contracts are at least to some extent relational, ${ }^{39}$ in the sense that the relational values which made the bargaining process possible in the first place must be understood to continue to permeate the contract throughout its lifecycle. At first blush, a proposition which regards all contracts as relational goes against the dominant presumption regarding the nature of the contracting parties as self-interested agents, and therefore adversaries. Yet, at its core, contract is a relationship, albeit one with legal force, and requires the parties' adherence to values conducive to a relationship not only for it to come about in the first place, but also for it to be successfully completed down the line. I define these values as 'relational', because they are a necessary condition for a relationship between presumed rational agents to even be contemplated. In the context of the contract, such values must at least include an expectation of honesty, with respect to what the parties have and are willing to offer; and an expectation of reciprocity, in the sense that each party will be obtaining something they value out of the relationship in exchange for sacrificing something else. Indeed, the expectation of honesty is manifestly operationalised in the doctrines of misrepresentation and, indirectly, mistake, while as Macneil points out, ${ }^{40}$ the concept of reciprocity has been effectively institutionalised as the

\footnotetext{
${ }^{35}$ In contrast to the values in operation when the exchange is on the 'discrete' side of the spectrum: see also I Macneil 'Values in contract: internal and external' (1983) 78 Northwestern University Law Review 340 [hereafter, Macneil (1983)].

${ }^{36}$ Note eg Macneil's critique of the objective theory of contract (as applied in classical and neo-classical contract law) whereupon the parties' necessary consent to the contract terms is deduced not from reality but from 'objective manifestations of intent', rendering the whole established approach to consent fictitious: see Macneil, above n 18, at 883-884; cf R Barnett 'Conflicting visions: a critique of Ian Macneil's relational theory of contract' (1992) 78 Virginia Law Review 1175 at 1189-1190.

${ }^{37} \mathrm{cf}$ J Adams and R Brownsword Key Issues in Contract (London: Butterworths, 1995) pp 229-230, observing that the opportunism displayed by the plaintiff in Arcos $v$ Ronaasen was not recognised as bad faith. The facts in Baird, above $\mathrm{n}$ 3 , are a good example of this.

${ }^{38}$ See eg O Williamson 'Transaction-cost economics: the governance of contractual relations' (1979) 22 Journal of Law and Economics 233; I Macneil 'The many futures of contract' (1974) 47 Southern California Law Review 691.

${ }^{39} \mathrm{M}$ Eisenberg 'Why there is no law of relational contracts' (2000) 94 Northwestern University Law Review 805 at 813-817.

${ }^{40}$ Macneil, above n 35, at 347. Similarly, Campbell identifies as distinctly relational the obligation on a claimant in a contract dispute to mitigate the loss suffered as a result of the defendant's breach: D Campbell 'A relational critique of the Third Restatement of Restitution \$39’ (2011) 68 Washington \& Lee Law Review 1063 at 1067.
} 
doctrine of consideration, which is the very cornerstone of contract law. In short, the values underlying contract as an institution are fundamentally relational. Therefore, relational theory presents no definitional limitations for its operationalisation because its core tenets are already present within classical contract law itself.

But why are these core values relational? I contend that the answer lies in contract law's understanding of rationality as the pursuit of self-interest. In this light, a rational agent would only agree to transact with another equally rational agent where the latter has signalled that they will be complying with the terms of the bargain, otherwise the former risks losing both the resource they are willing to sacrifice and the resource they seek to obtain through the bargain. The parties' willingness to sacrifice a resource for the purposes of the bargain amounts to a self-imposed constraint on the pursuit of their respective self-interest. What follows from this is that the existence of any contract presupposes that both parties have, at least initially, agreed to constrain the pursuit of their self-interest in the context of the agreement. In other words, the existence of a contract presupposes the existence of two rational agents who have agreed to cooperate, in the sense of mutually and voluntarily constraining their conduct, long enough to achieve the objectives which drive the bargain, however short or discrete the transaction.

Thus, the third presumption upon which my argument is based may be formulated as follows: all contracts, regardless of duration or level of co-dependence between the parties, are relational to some degree; and this necessarily impacts contract law's understanding of the nature of a rational contractual party, not merely as an agent who pursues their own self-interest in the context of a bargain, but as an agent who has agreed to cooperate as a means of achieving that objective. Consequently, the relational interpretation of contracts should not be confined to those contracts which the law treats as quintessentially 'relational', in the sense of establishing an ongoing relationship of mutual reliance, such as the contractual joint ventures which Lord Leggatt addressed in both Yam Seng and Al Nehayan. Instead, the relational interpretation of contract should be introduced into the current legal framework by simply having classical contract law be re-interpreted contextually, in light of the relational norms that made the contract possible in the first place, so as to avoid the kind of, arguably, anomalous outcomes achieved in cases like Arcos $v$ Ronaasen. ${ }^{41}$

In Arcos, it will be remembered, the House of Lords ruled that goods sold under a contractual specification must correspond to that specification absolutely, which was itself a condition implied into the contract by the Sale of Goods Act 1893, section 13, then in force. Their Lordships expressly disregarded the relevant industry standards, as evident in the findings - on two occasions - of an industry umpire. Campbell argues that by doing so their Lordships dismissed the relevance of context crucial to the interpretation of the agreement. ${ }^{42}$ The effect of this was that their Lordships reversed the default standard in sale of goods from that of goods having to be of merchantable quality or fit for the purpose for which they were sold (already guaranteed by the Sale of Goods Act 1893, section 14) to that of goods having to absolutely correspond to their description in the contract (section 13). To be sure, Campbell does not disagree with a buyer being guaranteed absolute correspondence with the goods' contractual description, and therefore having the automatic right to reject them if that guarantee is breached, so long as the buyer has paid for such privilege. ${ }^{43}$

Therein lies the anomaly. A legal regime which claims to track market norms and values cannot expect sellers to guarantee absolute correspondence with the goods' description as a default without contradicting its own terms. ${ }^{44}$ This is because such expectation would lead to higher manufacturing costs, as suppliers would scramble to comply with the high standard of contractual performance, leading to higher prices, which in turn would be unacceptable to classically defined rational buyers. If given the choice, the latter would reasonably be expected to opt to pay less for goods that, on the

\footnotetext{
${ }^{41}$ Above $\mathrm{n} 27$.

${ }^{42} \mathrm{D}$ Campbell 'Arcos $v$ Ronaasen as a relational contract' in Campbell et al, above n 31, p 138.

${ }^{43}$ Ibid, p 162.

${ }^{44} \mathrm{cf}$ R Barnett 'The sound of silence: contractual defaults and contractual consent' (1992) 78 Virginia Law Review 821.
} 
one hand, do not correspond with their description absolutely, but, on the other, are guaranteed to be fit for the purpose they were bought, or, at the very least, to be of merchantable quality. Campbell's ultimate point is that if the judges in Arcos had properly considered the dispute in light of the context in which it was made in the first place, they would have concluded that the buyer did not in fact have the right to reject the goods outright, because the goods substantially corresponded to their description as per the default standard as to correspondence set by section 14. Making the Sale of Goods Act 1893, section 13 the default would be contradicting the purposes of the legal regime itself. Therefore, there are distinct advantages in a contextualist interpretation, even of 'discrete' contracts, in the sense that the undertaking of interpretation ultimately reflects more accurately the policy objectives of the law as declared.

\section{Limitations of contextualism}

In the previous section, I sought to establish that by relying on the presumption that all contracts are to some extent relational, injecting the contextualist methodology of relational theory into classical contract law is not only theoretically and practically plausible within the current legal framework, but also essential, so as to bring the operation of contract law in line with its own declared objectives. However, the relational methodology must be heavily qualified, because, as I argue in this section, relational theory's insistence on absolute contextualism has severe limitations. I demonstrate this by examining in detail a number of cases where contextualism was held to be key in the court's decision, yet the process by which their Lordships determined the context relevant to the court's inquiry was opaque at best and arbitrary at worst. The first of these cases, Baird Textiles v Marks \& Spencer, is one which relational theorists hail as a missed opportunity for the court to apply relational theory outright. The second and third cases, Investors Compensation Scheme $v$ West Bromwich Building Society and Mannai Investments Co v Eagle Star Life Assurance Co respectively, are those which established and formalised contextualism as a response to contractual ambiguity. Each of these cases represents a distinct approach to contextualism, in the sense that in each case the court uses a different framework by which to determine which context is relevant to the task of interpretation. Thus, in the first, the relevant context is determined by the case's own factual matrix, while in the second and third, the context is determined by reference to business common sense and industry practice respectively. I argue that every one of these approaches, on its own, is problematic. Ultimately, this section seeks to demonstrate that relying on absolute contextualism to ascertain the parties' reasonable expectations without an a priori, unifying framework by which to determine what context is relevant to the inquiry, will produce either arbitrary or simply un-replicable results, in the sense that every case will be distinguished on its own facts. I set out my proposed interpretative framework in the final section of this paper, where I apply it to the judgment in Rainy Sky SA v Kookmin Bank, where the Supreme Court crystallised its approach to contextualism based on the principles set out in Investors Compensation and Mannai Investments.

\section{(a) Case 1: determining the parties' reasonable expectations solely by reference to the case's factual matrix}

The problem with implementing relational contract theory in its most contextualist form is evident in Baird Textile Holdings $v$ Marks \& Spencer. ${ }^{45}$ The case concerned Baird Textiles (Baird), a decades-long supplier of retailer Marks and Spencer $(M \& S)$. Baird had been supplying textiles to $M \& S$ for 30 years. Their arrangement was not based on an express long-term contract to that effect, but on M\&S placing its orders with Baird in advance of every retail season every six months. After a total 60 orders, M\&S notified Baird that it would place no more orders with them. Baird sued, claiming inter alia that there was an overarching implied contract between Baird and M\&S, which required the latter to provide

\footnotetext{
${ }^{45}$ Above $\mathrm{n} 3$.
} 
Baird with reasonable notice before it ended their relationship, one so close that even the CEO of M\&S had described as 'symbiotic'. Baird calculated the period of reasonable notice at three years and justified the amount of time on the basis that it was necessary to allow Baird to disentangle its affairs from those of M\&S. Indeed, over the preceding three decades M\&S had come to be involved intimately in, and on many occasions even determine, Baird's most crucial business decisions, eg with regard to plant expansion, investment in specialised machinery and even the identity of Baird's other clients. M\&S's response was that in the absence of an express long-term contract, its legal relationship to Baird consisted of 60 separate, albeit consecutive, contracts and, therefore, any obligation to Baird begun with the placement of each order and ended with its completion. Affirming the High Court's decision at first instance, the Court of Appeal held that despite the ample evidence of co-dependency in the parties' relationship, the fact remained that, as with an implied contract term, an entire contract can only ever be implied as a matter of necessity and that, in this case, any such attempt would be impossible anyway for lack of certainty. ${ }^{46}$

How is the court to decide on the actual content of an agreement, with a view to enforcing it, when the parties themselves appear to have opposing impressions as to the very nature of their relationship? Campbell contends that this is possible by reference to the objective values which informed the relationship and made it possible in the first place. ${ }^{47}$ This is fair but let us consider the context in which those values operated. Baird was a well-established textile manufacturer when M\&S chose it to be one of its four major textile suppliers. All the same, the arrangement with M\&S was especially lucrative for Baird because of M\&S's own widely advertised policy with regard to its relationships with its suppliers, namely that the latter could rely on M\&S's long-term custom and support in return for complying with M\&S's own stringent manufacturing and marketing standards. However, throughout the 30-year relationship between the two, M\&S resisted signing an express long-term contract with Baird in order to retain flexibility in that side of its business. For its part, Baird apparently accepted this risky state of affairs in the face of a lucrative arrangement that took over $40 \%$ of its output and more than doubled its turnover. What should also be relevant here is that the relationship was one of co-dependency: M\&S had invested in the relationship at least as much as Baird had - if Baird suddenly decided to break from M\&S, the latter would have found itself one major supplier short and, therefore, in dire straits when it came to satisfying its retail demands. Baird could have used this fact to leverage an agreement, which, if nothing else, at least provided for a period of notice. My point here is that, Baird's understandable woes aside, M\&S had an equally valid claim in terms of context.

\section{(b) Case 2: determining the parties' reasonable expectations based on 'business common sense'}

Of course, examination of the relevant 'factual matrix' has long been established as an integral part of the task of contract interpretation. ${ }^{48}$ When, however, this 'factual matrix' is to determine the reasonable expectations of the contract parties, Brownsword asks 'relative to what precisely is a particular contractor's expectation "reasonable"? ${ }^{49}$ If, for instance, an industry-based paradigm of reasonableness becomes the sole compass for determining whether an expectation may be enforced, then the problem becomes one of how the industry-established norms are to be identified and related to the contract at hand, a task easier said than done. To my mind, this type of paradigm, held out as 'business common sense', refers to collective intuition, which is patently subjective and not necessarily what the rational agent who has decided to constrain the pursuit of their self-interest for the purposes of the

\footnotetext{
${ }^{46}$ Baird's second ground, promissory estoppel arising from the long-standing and extremely close relationship with M\&S, failed on the basis that an estoppel can only be the basis of a defence, rather than a cause of action in its own right.

${ }^{47}$ Campbell, above n 42.

${ }^{48}$ Reardon Smith Line Ltd $v$ Yngvar Hansen-Tangen [1976] 1 WLR 989 at 997.

${ }^{49} \mathrm{R}$ Brownsword 'After Investors: interpretation, expectation and the implicit dimension of the "new contextualism"' in D Campbell et al Implicit Dimensions of Contract: Discrete, Network and Relational Contracts (Oxford: Hart Publishing, 2003) p 105.
} 
bargain would have understood to be the case. In any event, Brownsword demonstrates the problem of relying on this type of paradigm as a guide to the task of contract interpretation through his analysis of the House of Lords' decisions in Investors Compensation Scheme v West Bromwich Building Society ${ }^{50}$ and Mannai Investments Co $v$ Eagle Star Life Assurance Co. ${ }^{51}$

In Investors Compensation the appellant handled claims by investors who, following the advice of independent financial advisers, had mortgaged their homes with certain building societies and used the advances to invest in equity-linked bonds. Due to falling equities and escalating interest rates, the investors suffered heavy losses and claimed compensation through the appellant, as their financial advisers had become insolvent. The appellant was a statutory body established pursuant to the Financial Services Act 1986, section 54 to provide a compensation fund for investors with unsatisfied claims against persons authorised under the Act to carry on investment business. Crucially, certain losses were excluded from the compensation scheme so that the investors were only partially compensated in every case. Here, having compensated the investors, the appellant sought to recover from the respondent building society in damages for breach of duty in common law and under the 1986 statute. The appellant could do this on the basis of a clause in its compensation claim form by which the investors assigned to the appellant all rights arising out of the transaction with the financial advisers and any third parties. The clause was, however, subject to an exception in section 3(b) of the appellant's form, whereby the investors retained absolutely the benefits of:

Any claim (whether sounding in rescission for undue influence or otherwise) that you have or may have against the West Bromwich Building Society in which you claim an abatement of sums which you would otherwise have to repay to that society in respect of sums borrowed by you from that society in connection with the transaction and dealings giving rise to the claim (including interest on any such sums).

Based on this exception, some investors commenced separate proceedings against the respondent building society for rescission of their mortgages and damages. Consequently, the issue arose as to whether the exception in section 3(b) was restricted to claims in rescission or covered any claim the investors may have against the building society seeking to reduce the amount repayable to the latter in respect of the mortgage loans, thus rendering the assignment clause void, at least with respect to claims against the building society. Being sued by both the investors and the appellant, the building society argued that on a simple reading of its wording, section 3(b) had to be interpreted in the broader sense, thus rendering the assignment clause void and the appellant's claim groundless. The alternative would be contrary to public policy, for it would mean the respondent would end up being sued for the same damages twice.

A majority of the House of Lords held that, taking account of the context and what a reasonable person with knowledge of the context would have understood from the wording of section $3(\mathrm{~b}),{ }^{52}$ the latter had to be interpreted as being restricted to claims in rescission. Lord Hoffmann argued that, along with the claim form itself, section 3(b) was obviously only meant to be read by lawyers. ${ }^{53}$ As laymen, investors were expected to rely on the explanatory note accompanying the claim form, paragraph 4 of which made unequivocally clear that the investor was giving up all rights against anyone else and transferred them to the appellant. Thus, while it was clearly the only document to legally govern the relationship between the investors and the appellant, the claim form had to be interpreted in light of the explanatory note. ${ }^{54}$ Dissenting, Lord Lloyd argued that section 3 (b) had to be interpreted

\footnotetext{
${ }^{50}$ [1998] 1 WLR 896.

${ }^{51}$ [1997] AC 749.

${ }^{52}$ Above $\mathrm{n} 50$, at $912 \mathrm{H}-913 \mathrm{E}$.

${ }^{53} \mathrm{Ibid}$, at $913 \mathrm{H}$.

${ }^{54}$ Addressing the claim form's specific reference to the right to rescission, Lord Hoffmann explained that this was necessary, for an investor who was entitled to rescission of the mortgage (eg if the building society had constructive knowledge of undue influence exercised by the financial adviser) or to an abatement of the debt by way of rescission could not assign this
} 
in the broader sense and that the explanatory note merely added to what a reasonable person would already have understood from the claim form itself; namely that they were expected to assign all claims but the right to sue the building society in order to reduce any outstanding debt on the mortgage. ${ }^{55}$ Lord Lloyd contended that such a conclusion must be obvious in light of the fact that the appellant expressly excluded certain types of claims from its compensation scheme, to the effect that it covered only between half and three quarters of the amounts claimed by the aggrieved investors. ${ }^{56}$ In other words, a broader interpretation of section 3(b) must have been what a reasonable investor would have understood and intended when they signed the appellant's claim form, for it would allow them to pursue additional compensation, at the very least to cover some of the losses which the appellant would not. Furthermore, addressing the respondent's argument that the commercial consequences of such interpretation would be 'ridiculous' (ie that in seeking to recover from the respondent - and other financial institutions and advisers in similar legal actions - the appellant would essentially be competing against the investors), Lord Lloyd observed that while the appellant was not a charity, it was also not a commercial organisation; as a statutory body its very essence was the compensation of aggrieved investors. In this light, there was nothing commercially unreasonable about an agreement providing that investors retain the whole of their rights against the respondent building society, while the appellant could recover from virtually everyone else involved. ${ }^{57}$ Therefore, the specific reference to rescission in section $3(\mathrm{~b})$ had to be interpreted as merely an example of the options that might be open to individual investors against the building societies who provided the mortgages. ${ }^{58}$

Ultimately, the debate in Investors Compensation boiled down to the question 'what context is relevant to the task of determining the reasonable expectations of the parties to the specific contract at issue'. More importantly, the debate did not revolve around the interpretation of the wording in section 3(b) qua wording, but rather of the section's wording in light of the case's 'factual matrix'. For the majority, led by Lord Hoffmann, the relevant context began and ended with the explanatory note accompanying the appellant's claim form. A reasonable investor would have read it and understood that they were expected to relinquish all rights to claim (apart from those arising from rescission). For Lord Lloyd, however, it was also necessary to consider the fact that the appellant had expressly excluded certain claims from its remit and that investors would only ever be partially compensated as a result. A reasonable investor would have understood that they could keep the right to claim at least against the building society, whether in rescission or damages. In other words, both sides to the debate were devoted to identifying the context that shaped the expectations of the investors.

However, despite its taking place at the highest level of adjudication, the debate in Investors Compensation still does not provide any guidance as to what made the majority's selection of facts from the case's 'factual matrix' more relevant to the dispute, than that of Lord Lloyd's. If anything, I contend that the Supreme Court in Rainy Sky SA v Kookmin Bank ${ }^{59}$ over a decade later supported Lord Lloyd's reasoning, for it held that where language can be interpreted in more than one way the court is entitled to choose the meaning consistent with business common sense and exclude all other meaning. My argument here is that if the law purports to be consistent with its own tenets, then the task of interpretation must start with the court's understanding of the reasonable person as a rational agent pursuing their self-interest after properly reflecting what this requires in the circumstances. In this light, business sense should have been understood from the point of view of the reasonable investor, signing the appellant's claim form and having knowledge of the relevant background, which includes the explanatory note as well as the appellant's restrictions in its compensation policy.

right to someone else, in any event: a claim in rescission could only be made by the owner of the mortgaged property; ibid, at 916A-F.

${ }^{55} \mathrm{Ibid}$, at $903 \mathrm{~B}-\mathrm{C}$.

${ }^{56}$ Ibid, at $905 \mathrm{C}$.

${ }^{57}$ Ibid, at $905 \mathrm{E}-\mathrm{F}$.

${ }^{58} \mathrm{Ibid}$, at $902 \mathrm{H}-903 \mathrm{~A}$.

${ }^{59}[2011]$ UKSC 50. 
If this is the case, then Lord Lloyd's reasoning reflects the thought process of the reasonable investor more closely than the alternative presented by the majority, because the latter expects the reasonable investor to act in accordance with what made business sense for the appellant, which is both improbable and contradictory, given the law's understanding of contractual parties as self-interested agents.

\section{(c) Case 3: determining the parties' reasonable expectations based on industry practice}

Investors Compensation demonstrates that there is an alarming element of arbitrariness in determining what context is relevant in the task of ascertaining the reasonable intentions of parties to a contract, particularly where the language of the document actually governing the dispute is vaguely drafted. Do things improve where the court is afforded a slightly more reliable compass, along the lines of, say, industry practice? Brownsword argues that they do not, ${ }^{60}$ as demonstrated in Mannai Investments, where the House of Lords sought to determine the reasonable expectations of a commercial person by taking into account standard commercial practice. In particular, the House of Lords in Mannai Investments had to consider the validity of a notice to terminate two identical 10 -year commercial leases, which bore the wrong date for termination. In particular, the tenants sought to terminate in accordance with a break clause in the leases, which provided them with a single opportunity to terminate the leases prior to the expiry of their fixed 10-year term. The break clause required the tenants to serve the landlord written notice of no less than six months determining each lease 'on the third anniversary of the term commencement date', which in this case was 13 January 1995 for both (the leases having been signed on 13 January 1992). Unfortunately, in their identical written notices the tenants indicated that the date of termination was 12 January 1995. A majority of the House of Lords held that the issue was how a reasonable recipient, rather than the landlord in this particular case, would have understood the notices, which had to 'be construed taking into account the relevant objective contextual scene'. ${ }^{61}$ Applying this test, Lord Steyn held that:

a reasonable recipient with knowledge of the terms of the lease and third anniversary date (13 January), ... would have appreciated that the tenant wished to determine the leases on the third anniversary date of the lease but wrongly described it as the $12^{\text {th }}$ instead of the $13^{\text {th }}$. The reasonable recipient would not have been perplexed in any way by the minor error in the notices. The notices would have achieved their intended purpose. ${ }^{62}$

Lord Steyn then went on to address the long-established argument put forward by Lord Greene MR in Hankey $v$ Clavering that:

Notices of this kind are documents of a technical nature, technical because they are not consensual documents, but, if they are in proper form, they have of their own force without any assent by the recipient the effect of bringing the demise to an end. ${ }^{63}$

As such, Lord Greene continued, where they are clear and specific but inaccurate as to a detail, such as the date of termination, the court cannot ignore the inaccuracy and substitute the correct detail 'because it appears that the error was inserted by a slip'. ${ }^{64}$ This is because 'that would not cure the defect because the document was never capable on its face of producing the necessary legal consequence. ${ }^{65}$ In response, Lord Steyn pointed out that documents of this type (commercial contracts and unilateral contractual notices) tend to be construed in a commercially sensible way, or how a

\footnotetext{
${ }^{60}$ Brownsword, above n 49, p 113.

${ }^{61}$ Mannai Investments, above n 51 , at $767 \mathrm{G}-\mathrm{H}$.

${ }^{62} \mathrm{Ibid}$, at $768 \mathrm{H}-769 \mathrm{~A}$.

${ }^{63}[1942] 2 \mathrm{~KB} 326$ at $329-330$.

${ }^{64}$ Ibid.

${ }^{65}$ Ibid.
} 
reasonable commercial person would interpret them, the reason for this approach being 'that it is more likely to give effect to the intention of the parties'. ${ }^{66}$ In other words, the court should reason based on what a person with knowledge of commercial practice would have considered reasonable in the circumstances, ie that, here, the tenant clearly wished to terminate the leases in accordance with their break clause.

This is fair, but one must take into account all aspects of commercial practice, lest some relevant context is overlooked. So, as Brownsword observes ${ }^{67}$ and a dissenting Lord Goff alludes to, ${ }^{68}$ it should be relevant to this process that termination clauses in commercial leases are often worded in such a convoluted way, precisely so as to make it difficult for the tenant to comply. In other words, a commercial person with knowledge of relevant practice would recognise such technical documents for the 'traps' that they are. Indeed, Lord Goff pointed out that all the tenant had to do in order to comply with the break clause was to simply reproduce the wording in the clause itself thus avoiding the 'trap' altogether. ${ }^{69}$ Instead, the tenant made a reference to a specific date - which turned out to be wrong, for the wording of the break clause appeared intentionally vague in that regard. Thus, according to Brownsword and Lord Goff, if the objective relevant context was determined by what a commercial person with knowledge of the background would consider reasonable, then on Lord Steyn's reasoning, the notices should have been deemed ineffectual.

With respect, I submit that Lord Steyn's reasoning in Mannai Investments was ultimately in keeping with both business common sense and, to my mind, the industry standard - trap clause and all. I contend that if the law is to be consistent with its own declared objectives, then the task of interpreting the parties' intentions ex post must consistently rely on the law's ex ante presumptions as to the parties' rational disposition. This gives rise to several logical implications. Thus, as I noted in the previous section, if the law is to presume that commercial parties are rational first and foremost, then, regarding any bargain whatsoever, it must also presume that the parties must have constrained the pursuit of their self-interest at least in the context of the bargain. Otherwise, the bargaining process could not take place at all, for the parties must understand the other to be adhering to the barest of relational norms, such as expectations of honesty and reciprocity, before bargaining with each other can take place.

Yet, the 'trap' clause in Mannai Investments does not reflect a relational norm. Instead, on Lord Goff's view, it is merely an opportunistic ploy designed to catch the tenant out in confusion. If this is the case, however, a rational agent who the law must presume has decided to constrain the pursuit of their self-interest in the context of the bargain, cannot be regarded as having understood the effect of this particular clause to be what was apparently intended by its drafter. This is because, the clause, if interpreted the way it was apparently intended by the drafter, would simply contradict the norms which allowed the contract between self-interested parties to be made in the first place. Thus, this interpretation could not have been what the rational agents in question must have intended at the time of contracting. On this view, therefore, Lord Steyn's approach is in keeping with what a rational agent would have intended in the circumstances, if they had properly reflected on what their selfinterest requires.

Ultimately, the adjudication process in Mannai Investments, as with Investors Compensation, boiled down to the task of choosing one set of facts ostensibly relevant to the dispute over another set of facts, arguably, just as relevant to the dispute. There was no clear justification as to why Lord Goff's reasoning failed to satisfy the majority, despite the fact that it was consistent with established judicial precedent and, more importantly from a contextualist point of view, took account of actual commercial practice, which both sides to the debate accepted from the beginning was relevant to the case's factual

\footnotetext{
${ }^{66}$ Mannai Investments, above n 51, at 771A-B, quoting Lord Diplock's speech in Antaios Compania Naviera SA v Salen Rederierna $A B$ [1985] AC 191 at 201: 'if detailed semantic and syntactical analysis of a word in a commercial contract is going to lead to a conclusion that flouts business common sense, it must be made to yield to business common sense'.

${ }^{67}$ Brownsword, above n 49, p 114.

${ }^{68}$ Mannai Investments, above n 51, at 759E-G.

${ }^{69} \mathrm{Ibid}$, at $757 \mathrm{E}-\mathrm{F}$.
} 
matrix. Thus, in the absence of clear principle as to what makes certain pieces of the factual matrix relevant to the dispute ex ante, it is impossible to instil any certainty in a contextualist adjudication process ex post: the outcome will most likely depend on judicial intuition, which is the only way, in my opinion, to explain the selection of relevant facts by the majority in both Investors Compensation and Mannai Investments.

\section{Introducing a new framework for interpreting the reasonable expectations of contractual parties}

The contextualist approach adopted by the House of Lords in both Investors Compensation and Mannai Investments eventually became the status quo in cases where the court is faced with two competing interpretations of the same contractual term. Yet, the intuitive nature of the process determining what, ultimately, constitutes 'business common sense' remains unchanged. Thus, in Rainy Sky SAv Kookmin Bank the Supreme Court tackled a dispute between the buyers of six ships to be constructed by a South Korean company, which became insolvent during the contract period, and the latter's guarantor bank. The appellant buyers had agreed to pay the purchase price over six instalments on the condition that the seller's guarantor would refund every instalment, if it transpired that the seller would fail to deliver the ships. The condition was recorded in a bond, which set out the events that would trigger the bank's obligation to issue the refunds but did not include the possibility of the seller's insolvency in that list. The prospect of insolvency, however, was listed in the main contract of sale between the appellants and the seller as possible grounds for termination of the contract, upon which the buyer would be entitled to be refunded the purchase price. When it transpired that the seller had entered insolvency proceedings under Korean law, the buyers sought to enforce the refund condition. However, the bank refused to comply on the ground that it was only bound by the bond, which made no reference to insolvency as being a trigger for the condition, even though it did make reference to 'all sums due under the contract [of sale]'. The issue then was whether the parties had intended the bond to be read in light of the termination clause in the contract of sale or whether each document stood on its own strength independent of the other. Palmer LJ in the Court of Appeal held that the documents had to be read independently of each other, because to do otherwise would be substituting the court's own understanding of business common sense for that of the parties. The Supreme Court, however, held that the bond had to be read in the overall context of the contract of sale and its surrounding circumstances. In this regard, it was relevant that the buyers' financiers would have never agreed to finance the construction of the ships, had the very real prospect of the seller's insolvency not been included in the circumstances that triggered the refund provisions in the bond.

While I do not disagree with their Lordships' conclusion with respect to the interpretation of the refund provision, I submit that their ratio placed undue weight to the expectations of the buyers and effectively ignored those of the seller. Thus, as with Investors' Compensation and Mannai Investments, the Court's contextualist analysis relied on the selection of one set of relevant facts over another without providing sufficient justification for this choice. I submit that this approach renders the contextualist application of the law unduly arbitrary. Indeed, if contract law is to be rational, in the sense of being consistent with its own declared objectives, then it must reason from premises that place equal weight on the reasonable expectations of both parties, given that the contracting process is a quintessentially collective, if not outright collaborative, enterprise, whether viewed from a classical or relational point of view. Therefore, when addressing which interpretation of the two documents made 'good business sense', the Supreme Court should have also taken into account the seller's reasonable expectations rather than rely solely on the buyer's understanding of the refund condition. To my understanding, the Court omitted this equally relevant set of facts, because despite its insistence on the importance of context in determining what a reasonable commercial person would have understood as 'good business sense', its approach to the contract as an institution is that it is inherently adversarial, rather than collaborative. The result appears to be that their Lordships feel compelled to choose one party's interpretation of the facts, over the other's. 
It is in response to this conundrum that my reimagined relational interpretation of contracts may provide a solution. By viewing the contract as an inherently collaborative exercise, the Court may make a determination on what constitutes 'good business sense' based on what the parties must have both understood to be the case when the contract was made. What is novel here is that it takes the parties' common basis for the contractual process and uses it as the framework by which to determine which context is relevant in interpreting the parties' intentions at the time the contract was made. I submit that the common basis for commercial contracts of any type starts with the parties' mutual inclination to constrain the pursuit of their self-interest in the context of the bargain, in the sense of being willing to sacrifice a resource in order to acquire something else in return. This assumption is essential, as without it a bargain between self-interested commercial parties would not be logically possible. Because the law presumes that commercial parties tend to reason from self-interested premises, the process of calculating the extent of a sacrifice in the context of the bargain must be presumed to be equally self-interested. In other words, for presumed rational agents to agree to a bargain, the bargaining process itself must be presumed to be rational. Thus, the law must presume that neither party can have agreed to a bargain by which they alone will be worse off than they would have been had there been no bargain at all. Consequently, each party must be presumed to have made such concession as would represent the least amount of sacrifice, but would return the highest possible benefit in the circumstances. It is this method of calculating the parties' respective concessions that I regard as the common basis of any commercial contract.

In the context of the parties in Rainy Sky, this type of concession would be reflected in the buyers' agreeing to pay the purchase price of the ships in instalments prior to the ships being ready for delivery. From the seller's point of view, this type of concession would be reflected in actively agreeing to a refund condition, which must have included the prospect of insolvency as one of its triggers, otherwise the buyers' financiers would never have agreed to provide the funds for the construction of the ships so far ahead of delivery being possible. Being a part of this industry, the seller must be presumed to have been aware of the risk-averse nature of financing banks in making this concession with respect to the refund condition. For both parties the benefit obtained from their respective concessions is a number of ships at a presumably fair price for the buyers and, for the seller, guaranteed cash flow over a number of months while the ships were being constructed.

I submit that this type of interpretative framework, which identifies the parties' respective concessions as the relevant context informing the court's inquiry, has two advantages. The first is that it addresses the arbitrariness, unpredictability and bias inherent in forming a judgment while reasoning from premises that take into account primarily one side's intentions and understanding at the time the contract was made. The second advantage is that it is applicable to any type of commercial contract irrespective of class, barring only those contracts which are subject to a specific statutory regime (such as consumer, insurance, conveyance and employment contracts). To be sure, the process of identifying the parties' respective concessions will be more straightforward in conventionally defined relational or synergistic contracts, such as the type of contractual joint venture encountered in Yam Seng and Al Nehayan, briefly considered at the beginning of this paper. In such cases, the parties' respective concessions are naturally easier to identify, not only because they are often spelled out in the agreement itself, but also because the economic and social drivers behind this type of contract, such as risksharing and resource-pooling, are well-established in both economic theory and practice. Rather, this interpretative framework comes into its own when addressing the type of contract that ranges from the more synergistic, such as the supply chain in Baird Textiles, to the more discrete, such as the supply agreement in Rainy Sky, where the factors driving the parties' respective intentions may well be unique to each party. In such cases, seeking to ascertain the parties' intentions will necessarily lead to bias, because in the context of litigation the court is naturally inclined to choose one party's understanding of events over the other's. The framework proposed here seeks to ascertain the parties' intentions by reference to the contract's surrounding context as informed by the common basis upon which the parties calculated their respective concessions. This allows for a more objective reasoning process, which not only reflects the contract's surrounding context more accurately by taking into 
account of both parties' relevant understanding and intentions, but also reflects more closely the objectives of contract law as declared.

\section{Conclusion}

The four cases examined above demonstrate the difficulty in authoritatively identifying the relevant context, even where all parties involved in the adjudication process are clearly inclined to follow a contextualist - rather than literal - approach to the dispute at hand. This, I submit, is the most significant limitation of relational contract law, both with respect to the theory itself and its practical application. The difficulty stems from the fact that without an objective principle to guide the task of interpretation, what determines which context is relevant and how it is to be related to the issue at hand ultimately depends on the adjudicator's intuition, which is patently subjective. ${ }^{70}$ This problem is compounded by the adversarial nature of litigation itself, in which the adjudicator is expected to choose one party's version of events despite the fact that by its very nature contract is a collaborative undertaking. This moves the adjudication process further away from the declared objective of contract law, which is to give effect to the reasonable expectations of the parties at the time the contract was made, namely a time where the parties' priority must have been cooperation rather than competition.

This is not to say that contextualism on its own can never be a successful paradigm for the resolution of contractual disputes. ${ }^{71}$ It must, however, operate abstractly. For instance, in the context of the research and development economy, which features primarily collaboration through joint ventures, Jennejohn dismisses contextualism at the outset, because, on a practical level, it tends to focus on trade norms and the course of past dealings between the parties to determine their disputes. ${ }^{72} \mathrm{He}$ argues that (a), by definition, the innovation economy does not have established trade norms to be used as an interpretation tool, because the innovation economy consists in economic agents coming together to create entirely new products, for which no market yet exists; and (b) in a joint venture formed in a market vacuum between two parties who have not collaborated before, reliance on the course of their past dealings is meaningless, for they tend to deal with issues as they arise. Yet, Jennejohn proposes a novel adjudication model for the innovation economy, which is not only fundamentally relational but also contextualist. Briefly, this model, which Jennejohn calls 'experimentalist', holds that once a third-party adjudicator becomes involved (the parties having exhausted all other dispute resolution processes set out in their contract), instead of producing a judgment awarding a one-off remedy to the aggrieved party, the adjudicator establishes an enforcement programme with milestones that parties will each be required to meet as appropriate. This is profoundly relational because it seeks to preserve the relationship, which through a one-off judgment would likely collapse following its enforcement, as it expects the parties to continue addressing their issues, albeit with official direction and supervision. Jennejohn's model is also distinctly contextualist, albeit on an abstract level, for it takes into account and addresses the unique properties of the innovation economy.

By contrast, the contextualist albeit objective framework for which I advocate here seeks to ascertain the relevant context informing the contract not by reference to each party's unique intentions when examined in a vacuum, but by reference to the common basis upon which the parties, as presumed rational agents, must have calculated their respective concessions so as to make the contract possible in the first place. This type of reasoning should apply to every type of commercial contract (which is not already governed by a specific statutory regime) irrespective of class, duration or degree of co-dependence. Finally, it must be stressed that the purpose of a contextualist interpretation of contract cannot be to rectify a bad bargain but to fill in gaps in an incomplete one (where relevant). This is because, fundamentally, the task of interpretation seeks to ascertain the (true) intention of the parties at the time of contracting. Therefore, for the law to rectify a bad bargain (in the absence of

\footnotetext{
${ }^{70}$ See the relevant discussion in Lord Hoffmann 'Anthropomorphic justice: the reasonable man and his friends' (1995) 29 (2) The Law Teacher 127.

${ }^{71}$ See eg Amlin Corporate Member v Oriental Assurance Corpn [2014] EWCA Civ 1135.

${ }^{72} \mathrm{M}$ Jennejohn 'Contract adjudication in a collaborative economy' (2010) 5(2) Virginia Law \& Business Review 173.
} 
consent-invalidating factors) would be to contradict its declared objective, because, bad bargain or not, the parties must have intended to make it and such intention warrants being given effect. A case in point is Baird. Here, contextualism would not necessarily have assisted the 'wronged' party. This is because the parties were fundamentally not ad idem with respect to the nature and extent of their relationship, with one insisting on a 'discrete' relationship structure (having successfully created a supply chain of supplier-retailer to its own specification) and the other treating the relationship as, essentially, one of partnership. In short, there was no incomplete contract for contextualism to rectify, because the demonstrable common objective went only as far as the subject matter of each of the orders placed by the retailer to the supplier. Surely, this fact would have been relevant to the enquiry as much in terms of context, as it was in terms of classical contract theory.

Thus, when applied on a more abstract level, contextualism can prove indispensable as an adjudication tool, which is amply demonstrated by such areas as insurance, construction and product liability law, all of which are fields of contract (and tort) law that have been informed by the factual similarities of the cases arising in their respective contexts and were developed accordingly. ${ }^{73} \mathrm{~A}$ relational law of contracts ought to operate at a similar level of abstraction, namely as a default legal structure informed by what the parties would have intended if they purported to act rationally, ie if they had properly reflected on what their self-interest requires in circumstances where their choices are dependent on the choices of another equally self-interested agent. That is to say, a fundamentally contextualist approach to contract adjudication must be qualified heavily so as to conform to a web of a priori assumptions on the nature and behaviour of rational economic agents, if the logical and practical problems it raises are to be overcome.

\footnotetext{
${ }^{73}$ J Feinman 'Relational theory in context' (2000) 94 Northwestern University Law Review 737 at $744 \mathrm{ff.}$

Cite this article: Gounari Z (2021). Developing a relational law of contracts: striking a balance between abstraction and contextualism. Legal Studies 41, 177-193. https://doi.org/10.1017/lst.2020.23
} 